\title{
Distribution of Late Cenozoic Volcanic Vents in the Cascade Range: Volcanic Arc Segmentation and Regional Tectonic Considerations
}

\author{
Marianne Guffanti \\ U.S. Geological Survey, Reston, Virginia \\ Craig S. Weaver \\ U.S. Geological Survey, Seattle, Washington
}

\begin{abstract}
Spatial, temporal, and compositional distributions of approximately 4000 volcanic vents formed since $16 \mathrm{Ma}$ in Washington, Oregon, northern California, and northwestern Nevada illustrate the evolution of volcanism related to subduction of the Juan de Fuca plate system and extension of the Basin and Range province. Vent data were obtained from published map compilations and include monogenetic and small polygenetic volcanoes in addition to major composite centers. On the basis of the distribution of 2821 vents formed since $5 \mathrm{Ma}$, the Cascade Range is divided into five segments, with vents of the High Lava Plains along the northern margin of the Basin and Range province in Oregon forming a sixth segment. Some aspects of the Cascade Range segmentation can be related to gross structural features of the subducting Juan de Fuca plate. The orientation of the volcanic front of segments one and two changes from NW in northern Washington to NE in southern Washington, paralleling the strike of the subducting Juan de Fuca plate. Segments one and two are separated by a $90-\mathrm{km}$ volcanic gap between Mount Rainier and Glacier Peak that is landward of the portion of the subducting plate having the least average dip to a depth of $60 \mathrm{~km}$. A narrow, N-S trending belt of predominantly andesitic vents in Oregon constitutes a third segment, which is landward of the seismically quiet portion of the subduction zone. The narrowness of this segment may indicate steep dip of the subducting plate beneath the Cascade arc in Oregon. Vents are sparse between segment four (containing the Mount Shasta and Medicine Lake centers) and segment five (containing Lassen Peak), where the Juan de Fuca and Gorda North plates are characterized by differing age, amounts of subcrustal seismicity, and probably geometry. From the relation between seismicity at depth of $60 \mathrm{~km}$ and the position of the volcanic front of vents formed since $5 \mathrm{Ma}$, transitions between subducting-plate segments of varying geometry likely occur near boundaries between independently defined volcanic segments in northern Oregon and northern California. In the Basin and Range province east of the Cascade arc, volcanism migrated into the region adjacent to the Cascade Range during the interval 5-10 Ma. Since $5 \mathrm{Ma}$, the impingement of the two provinces is characterized by cessation of basin-range volcanism in southern Oregon, continuation of basaltic volcanism in northeastern California where the impingement process may not yet be complete, and contraction of the area of mafic volcanism around Mount Shasta, Medicine Lake, and Lassen Peak. In central Oregon where the northern margin of basin-range volcanism (the High Lava Plains) intersects the Cascade arc, impingement of basin-range extensional volcanism approximately coincides in time and space with the development of the High Cascade graben between Three Sisters and Mount Jefferson.
\end{abstract}

\section{INTRODUCTION}

Late Cenozoic volcanism in the Cascade Range of the Pacific Northwest is widely attributed to subduction of the Juan de Fuca plate system beneath the North American plate. Beyond this first-order relation between volcanism and subduction, volcanic processes vary along the Cascade arc in time and space. For example, the amount and style of Cascade volcanism during the past 5 m.y. are significantly different north and south of Mount Rainier, Washington. Isolated stratovolcanoes in northern Washington contrast with composite volcanoes surrounded by fields of numerous, monogenetic, mafic volcanoes south of Mount Rainier in southern Washington, Oregon, and northern California [Luedke and Smith, 1981, 1982].

Recently, attempts have been made to use the distribution of late Cenozoic volcanism to improve tectonic models of the interaction between the Juan de Fuca and North American plates. These models are based on the assumption that the differences observed in the amount of volcanism are the result of differences in the manner of interaction between the two

This paper is not subject to U.S. copyright. Published in 1988 by the American Geophysical Union.

Paper number 7B6056. plates. Such plate models postulate that the concentration of volcanism at a few major stratovolcanoes in Washington and British Columbia is the result of compression in the North American crust, whereas the widespread volcanism to the south is thought to reflect crustal extension [Weaver and Smith, 1983; Rogers, 1985; Weaver and Michaelson, 1985]. Suggested reasons for the difference in the crustal stress regime within the volcanic arc include areal variations in the convergence velocity between the plates [Rogers, 1985] and variations in the dip of the Juan de Fuca plate [Weaver and Michaelson, 1985; Michaelson and Weaver, 1986]. Also, extension in the Basin and Range province, which lies directly east of the Cascades in southern Oregon and northern California, has been linked to basaltic magmatism in the Cascade Range [Priest et al., 1983; Smith and Luedke, 1984].

Models that relate the distribution of volcanism to the regional tectonic framework typically make little distinction with regard to the nature of volcanic products, and attention commonly is focused on major stratovolcanoes [e.g., Hughes et al., 1980]. We extend the treatment of volcanism and investigate the distribution of middle Miocene and younger volcanic vents in the Pacific Northwest with respect to time, space, and composition. Our data set includes monogenetic vents, minor stratovolcanoes, and shield volcanoes in addition 
to the major, physiographically dominant, composite centers. Our intent is to provide a range-wide volcanic framework focusing on the past $5 \mathrm{~m}$.y. Our analysis accepts the premise of Smith and Luedke [1984] that the distribution of volcanic vents can be a better indicator of the area of regional volcanism than the outcrop area of eruptive products. On the basis of vent patterns we subdivide the Cascade Range into five segments which we correlate with structural elements of the Juan de Fuca and Gorda plates. We also examine westward migration of Basin and Range volcanism into the Cascade region.

\section{Vent Data}

The latitude and longitude of approximately 4000 volcanic vents formed since $16 \mathrm{Ma}$ in Washington, Oregon, northern California, and northwestern Nevada were digitized from the map compilations of Luedke and Smith $[1981,1982]$. In addition to determining these locations we adopted the classifications of Luedke and Smith [1981, 1982] in which each vent was assigned by them to one of eight age groups (in years: $<100 ; 100-1000 ; 1000-10,000 ; 10,000-100,000 ; 100,000-1$ million; 1-5 million; 5-10 million; 10-16 million), to one of four compositional categories on the basis of $\mathrm{SiO}_{2}$ percentage (basalt, 46-54\%; andesite, 54-62\%; dacite, 62-70\%; rhyolite, $>70 \%$ ), and to one of seven vent types (cinder cone, dome, shield, stratovolcano, neck, maar, dome cluster). Age determinations used in the map compilations were based on several hundred radiometric dates (obtained primarily using K-Ar method), general morphology of volcanic edifices, magnetic polarity, and stratigraphic relations of volcanic units. Ages less than about 10,000 years are relatively less constrained than in older time brackets because of the paucity of carbon 14 analyses in the compilations (R. G. Luedke, oral communication, 1987).

The vent data have some notable limitations. As a result of erosion and burial of vents by younger rocks, the data provide minimum values for the number and areal extent of any given temporal distribution of vents. The problem of detecting vents is more difficult for increasingly older age divisions. We do not estimate the volume of rock erupted from each vent, so volcanism at polygenetic volcanoes is underrepresented by vent counts. Luedke and Smith [1981, 1982] used available chemical analyses to assign vents to compositional categories that differ slightly from those defined by some other workers; for example, andesite is defined as $53-63 \% \mathrm{SiO}_{2}$ by Gill [1981]. The andesite category in this study does not distinguish basaltic andesite $\left(53-57 \% \mathrm{SiO}_{2}\right)$, a compositional category common in central Oregon [e.g., Sherrod, 1986; Hughes and Taylor, 1986]. Nor does the compositional classification highlight rocks of distinctive composition that may have tectonic significance, for example, the mildly alkalic lavas in southern Oregon described by Walker and Naslund [1986] and lowpotassium olivine tholeiites similar to those that occur in the adjacent Basin and Range province [Hart et al., 1984].

\section{Distribution of Volcanic Vents}

Volcanism has migrated west to northwest in parts of Oregon, California, and northwestern Nevada since $16 \mathrm{Ma}$ [MacLeod et al., 1976; Christiansen and McKee, 1978; Smith and Luedke, 1984]. To illustrate this migration, we plot vents formed from 5 to $16 \mathrm{Ma}$ (Figure 1). The area of younger vents is outlined to indicate where older vents probably are obscured. The oldest vents (formed from 10 to $16 \mathrm{Ma}$ ) are lo- cated east of the Quaternary Cascade arc (Figure 1a), with the exception of two groups. Most of the vents in southeastern Oregon and northwestern Nevada in this time interval are basaltic or rhyolitic and have been interpreted to be part of the extensional volcanism of the Basin and Range province [Christiansen and Lipman, 1972; Christiansen and McKee, 1978]. Such volcanism is thought to involve the rise of mantlederived basaltic magma through extensionally thinned and faulted crust; the basaltic intrusions supply heat that melts siliceous crustal rock producing rhyolitic magma. Other notable features of the 10- to 16-Ma distribution include basaltic, andesitic, and rhyolitic vents in the Blue Mountains of northcastern Oregon, basaltic vents along the Oregon coast which Beeson et al. [1979] hypothesized may be extensions of flows from the Columbia Plateau, and a band of 10 andesitic vents roughly between $44^{\circ}$ and $45^{\circ} \mathrm{N}$ that constitute part of the Western Cascades. This last group comprises few vents but a relatively large outcrop area.

The distribution of vents formed from 5 to $10 \mathrm{Ma}$ (Figure $1 b$ ) is west of the 10 - to $16-\mathrm{Ma}$ distribution south of $43.5^{\circ} \mathrm{N}$. Vents formed between 5 and $10 \mathrm{Ma}$ occur primarily south of $44^{\circ} \mathrm{N}$ (the approximate latitude of the Quaternary Three Sisters volcanic field). Most of the vents are basaltic shields and cones that form a wide, NNW trending belt east of the younger Cascade arc. Andesitic vents occur only in the most northwestern area of the distribution, southwest of presentday Newberry volcano. The paucity of vents in southeastern Oregon and northwestern Nevada from 5 to $10 \mathrm{Ma}$ is consistent with the model of Christiansen and McKee [1978], who proposed that extension in the northern Basin and Range began 17 to $14 \mathrm{Ma}$ and occurred throughout the region until $12 \mathrm{Ma}$, when faulting and volcanism subsequently became progressively concentrated outward along the brittle margins of the province.

An issue related to the interpretation of Figure 1 is the position of the Cascade arc since the middle Miocene. Tectonic rotation in a clockwise sense of segments of the crust of the Pacific Northwest has been documented by paleomagnetic measurements in Eocene to mid-Miocene rocks, and various paleogeographic reconstructions have been made that place the Oregon Coast Ranges and Western Cascades farther to the east in the early Tertiary (see, for example, Magill et al. [1981], Beck et al. [1986], Grommé et al. [1986]). In our judgement, the lack of paleomagnetic measurements in rocks less than 15 m.y. old, coupled with uncertainty about the tectonic mechanism of rotation, leaves unresolved the amount of rotation in the time period in which we are interested. We assume that during the past $15 \mathrm{~m}$.y. the Cascade arc has not significantly changed position as a result of tectonic rotation.

The distribution of 2821 vents since 5 Ma (Figure $2 a$ ) is in sharp contrast to that of older vents. The overall pattern of younger vents depicts the Cascade Range in Washington, Oregon, and California and delineates the northern margin of basin-range volcanism along the WNW trending High Lava Plains. Unlike the vent distributions of the two older intervals, the well-developed N-S trending volcanic arc is a salient feature. Although the older vent patterns suggest that there was apparently little volcanism in the Cascade Range prior to 5 Ma, we emphasize that products of the younger interval of volcanism obscure an indeterminate number of older vents, particularly in Oregon. In central Oregon, for example, late Miocene volcanic rocks that occur west and east of the Quaternary arc are recognized by Sherrod [1986] and Smith et al. [1987] to have vented from the site of the Quaternary arc. In 
Figure $2 b$ we have plotted the area of 5- to 16-Ma outcrops that lie west of the 0- to 5-Ma vents in Oregon [from Luedke and Smith 1982] to illustrate that there is geologic evidence of an andesitic arc prior to $5 \mathrm{Ma}$, although the vent data are sparse.

Between Mount Shasta and Mount Hood, the 0- to 5-Ma arc is a narrow belt approximately $30-50 \mathrm{~km}$ in width except where the High Lava Plains join the arc (Figure 2a). On both ends of the narrow belt the distribution of vents changes. To the north between Mount Hood and Mount Rainier, the zone of vents broadens to about $150 \mathrm{~km}$, and the vent distribution is less dense. Farther north, a 90-km gap separates Mount Rainier from Glacier Peak, and volcanism in northern Washington is limited to a few vents in the vicinity of the stratovolcanoes Mount Baker and Glacier Peak. To the south in California, the area of vents widens near both Mount Shasta and Lassen Peak compared to the distribution in Oregon (Figure $2 a$ ). The Lassen area is spatially separated from the continuous distribution of vents to the north.

Separate plots of andesitic (Figure $3 a$ ) and basaltic (Figure $3 b$ ) vents formed since $5 \mathrm{Ma}$ emphasize contrasts in compositional distribution. Within the N-S trending arc in Oregon (excluding vents around Newberry volcano where burial makes vent counts highly uncertain), approximately $60 \%$ of the vents are andesitic and $30 \%$ are basaltic. Near the Oregon-California border, there is a pronounced change in the ratio of andesitic to basaltic vents. Andesite predominates to the north, whereas basalts constitute about three fourths of vents to the south. The southern extent of the andesitic belt in Oregon has shifted northward about $35 \mathrm{~km}$ between 5 and 1 Ma (dashed horizontal lines on Figure $3 a$ ).

The distribution of basaltic vents (Figure $3 b$ ) generally is different from that of andesitic vents formed since $5 \mathrm{Ma}$ (Figure $3 a$ ). There are few basaltic vents between the Three Sisters field and the Oregon-California border and between Mount Jefferson and Mount Hood, in contrast to the dense distribution of andesitic vents over most of this region. In southern Washington, where the overall width of the vent zone broadens to about $150 \mathrm{~km}$, nearly $80 \%$ of the vents are basaltic. Some of these basaltic vents lie west of nearby andesitic vents, and others lie east of Mount Adams (note outlined area in Figure $3 b$ ). In northern California a few basaltic vents occur southwest of the main concentration of vents around Lassen Peak. To the east of the Lassen center, basaltic vents occur up to $75 \mathrm{~km}$ east of identified andesitic vents.

A similarity between the andesitic and basaltic distributions in Figure 3 is that south of Mount Hood, the western extent of basaltic vents coincides with the western extent of andesitic vents. A second similarity is that in northern California, few basaltic or andesitic vents occur between Mount Shasta and the Lassen volcanic center.

Basaltic vents occur considerably east of the andesitic vents in Oregon along the High Lava Plains (Figure $3 b$ ). This belt of vents is characterized by concentration of basaltic and rhyolitic rocks in the WNW trending Brothers fault zone [Walker, 1969]. The High Lava Plains are recognized as the northern transform boundary of maximum extension in the Basin and Range province, separating the Great Basin from the Columbia plateau province to the north [Lawrence, 1976]. The High Lava Plains intersect the Cascade Range in the region between Newberry volcano and Three Sisters volcanoes. The Cascade Range there is distinguished by increased density of both andesitic and basaltic vents as compared to areas to the north and south, by widening of the andesitic zone from about
30 to $80 \mathrm{~km}$, and by an eastward, $20-\mathrm{km}$ indentation of the western limit of andesitic vents near Three Sisters.

Vents formed since $1 \mathrm{Ma}$ (Figure 4) constitute about $60 \%$ of the identified 0- to 5-Ma vents, a proportion which reflects the greater difficulty of sampling older (1-5 Ma) vents. Although the overall pattern of 0 - to $1-\mathrm{Ma}$ vents is similar to that of the 0-5 Ma interval, Figure 4 shows that the areal extent of volcanism has contracted during the past $5 \mathrm{~m}$.y. Over this time period, the andesitic gap between Mount Shasta and Mount McLoughlin has widened; volcanism has localized around Mount Shasta, Medicine Lake, and Lassen Peak; and the zone of vents in southern Washington has narrowed. However, the narrowing in southern Washington may be partly an artifact of insufficient dating. The age of the Simcoe field (2-5 $\mathrm{Ma}$ ), southeast of Mount Adams, is solely constrained by three dates on samples from the southeast part of the field; nevertheless, parts of the field actually may be less than $1 \mathrm{Ma}$ based upon geomorphological characteristics of individual centers (W. Hildreth, oral communication, 1986).

From 0.1 Ma to the present (Figure 5), volcanism in the Cascade Range generally has been concentrated around the major composite volcanoes. Exceptions to this pattern are seen at the Indian Heaven basaltic field between Mount St. Helens and Mount Adams and vents north and south of Three Sisters (Figure 5a). Central Oregon in the vicinity of Three Sisters and Newberry is the most intense focus of venting during the past 100,000 years, although that area is not necessarily the site of greatest volumetric rate of magma discharge. A more detailed analysis of vent patterns in central Oregon at South Sister is provided by Bacon [1985]. About $12 \%$ of vents formed since 0.1 Ma are dacitic and rhyolitic (Figure $5 b$ ), and these silicic vents account for about $45 \%$ of dacitic and rhyolitic vents found in the Cascade Range (west of $121^{\circ} \mathrm{W}$ ) in the interval from 0 to $5 \mathrm{Ma}$. That nearly half of the silicic vents occur within only $2 \%$ of the time interval from 0 to $5 \mathrm{Ma}$ may reflect better preservation of young silicic vents, an episode of greater eruptive frequency of silicic volcanism during the past 100,000 years as compared with basaltic or andesitic volcanism or both.

\section{Volcanic Arc Segmentation}

On the basis of the distribution of 2821 volcanic vents formed since $5 \mathrm{Ma}$, we divide volcanism of the Pacific Northwest into six areal segments; five constitute the Cascade Range, and a sixth comprises the High Lava Plains (Figure 6). Segment one, the most northerly, contains the isolated stratovolcanoes Glacier Peak and Mount Baker, as well as the Cascade centers in British Columbia (Meager Mountain, Mount Cayley, and Mount Garibaldi) which we include for completeness although detailed vent data currently are not available. Segment two, from Mount Rainier to Mount Hood, encompasses a wide zone of primarily basaltic vents and includes the occurrence of basaltic vents east and west of the poorly defined andesitic arc. Segment three extends approximately $370 \mathrm{~km}$ from south of Mount Hood to the vicinity of the Oregon-California border and is characterized by a dense distribution of andesitic vents. We define the southern boundary of this segment by the decrease in the ratio of andesitic to basaltic vents, noted in the previous section. The fourth segment includes Mount Shasta and Medicine Lake volcano in California and their surrounding vents. Segment five includes the Lassen Peak area and is spatially isolated from the Cascade Range to the north in terms of the distribution of both andesitic and basaltic vents. This sixfold subdivision of 0 - to 


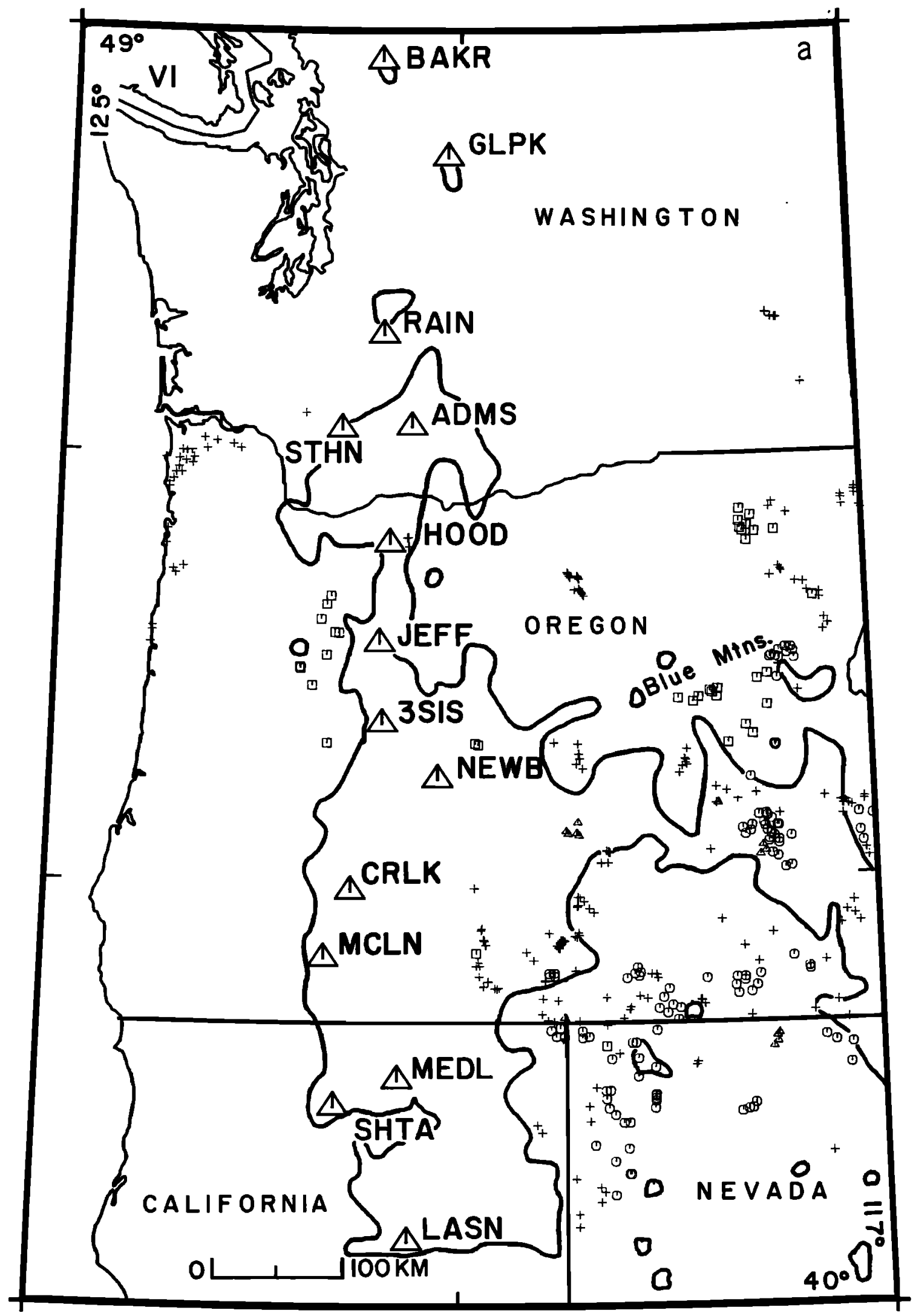

Fig. 1. Map of volcanic vents in Washington, Oregon, northeastern California, and northwestern Nevada: (a) 385 vents formed from 10 to $16 \mathrm{Ma}$, with outline of area of vents younger than $10 \mathrm{Ma}$ taken from Figures $1 b$ and $2 ;(b) 881$ vents formed from 5 to $10 \mathrm{Ma}$, with outline of area of vents younger than $5 \mathrm{Ma}$ taken from Figure $2 a$. Vent data from Luedke and Smith [1981, 1982]. Pluses, basalt; squares, andesite; triangles, dacite; circles, rhyolite. Large triangles indicate locations of major Quaternary volcanoes for comparison. BAKR, Mount Baker; GLPK, Glacier Peak; RAIN, Mount Rainier; STHN, Mount St. Helens; ADMS, Mount Adams; HOOD, Mount Hood; JEFF, Mount Jefferson; 3SIS, Three Sisters: NEWB, Newberry; CRLK, Crater Lake; MCLN, Mount McLoughlin; SHTA, Mount Shasta; MEDL, Medicine Lake; LASN, Lassen Peak; VI, Vancouver Island. 


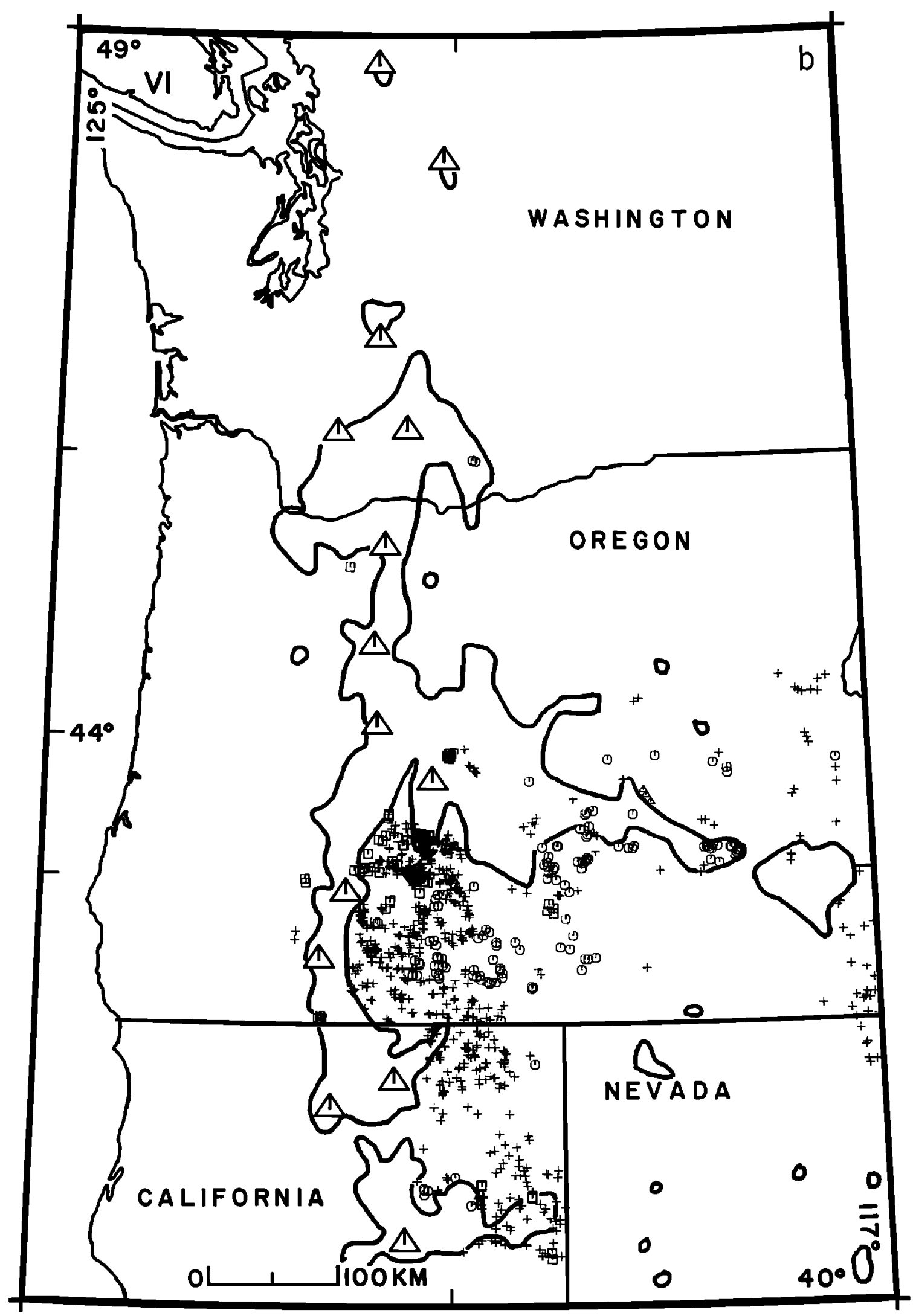

Fig. 1. (continued)

5-Ma vents also is applicable to the distribution of 0 - to 1-Ma vents (Figure 4).

Our segmentation model of the Cascade Range is based on different criteria than those commonly used to segment vol- canic arcs. Typically, segmentation of volcanic arcs has been based on the assignment of active stratovolcanoes to discrete linear segments, such that a segment has a stratovolcano at each end and includes two or more stratovolcanoes along a 


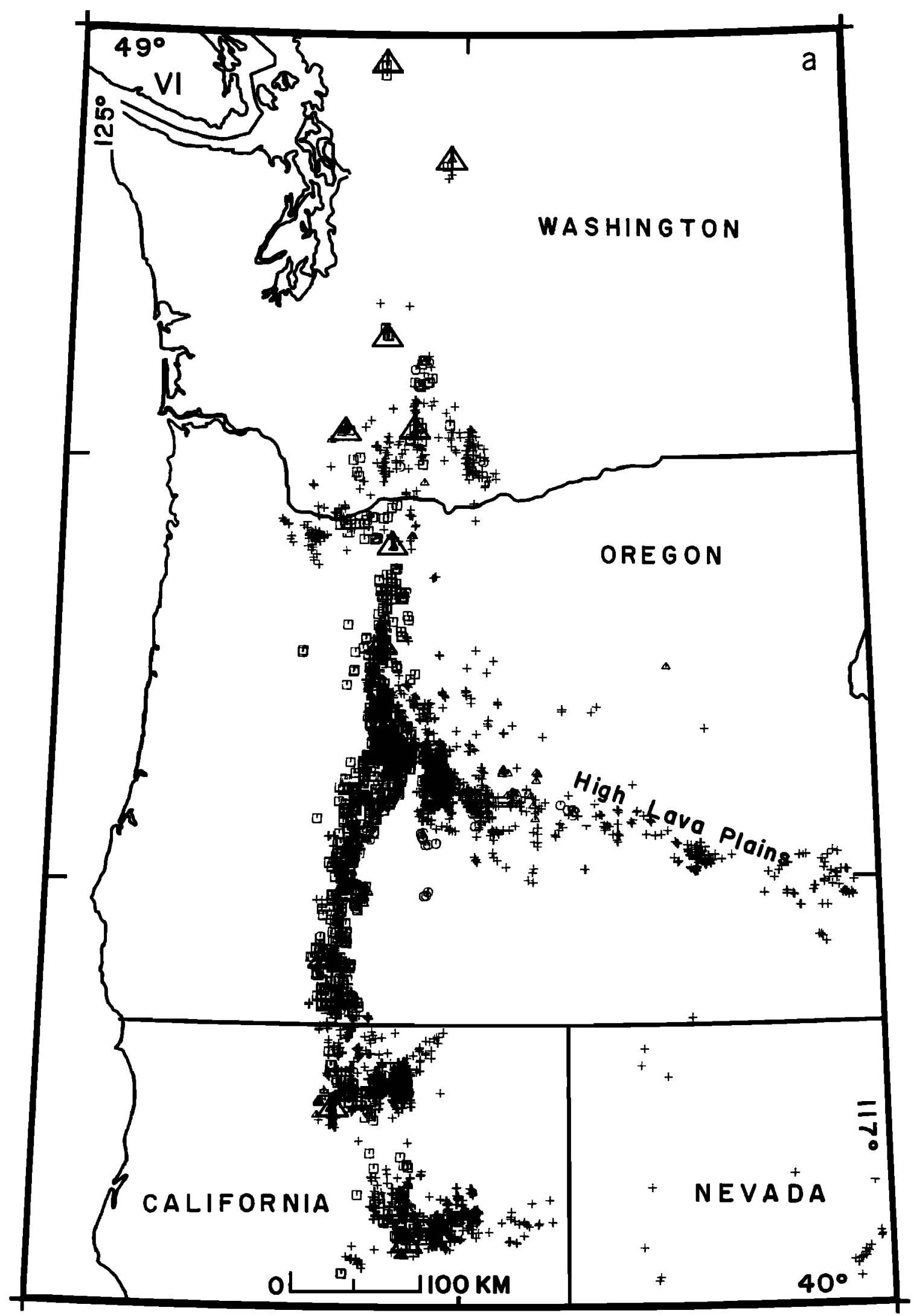

Fig. 2. (a) Map of 2821 volcanic vents in the Cascade Range and adjacent areas younger than $5 \mathrm{Ma}$; $(b)$ area of Cascade volcanic rocks formed from 5 to $16 \mathrm{Ma}$ that lie directly west of vents younger than $5 \mathrm{Ma}$. Data from Luedke and Smith [1981, 1982]. Pluses, basalt; squares, andesite; triangles, dacite; circles, rhyolite. 


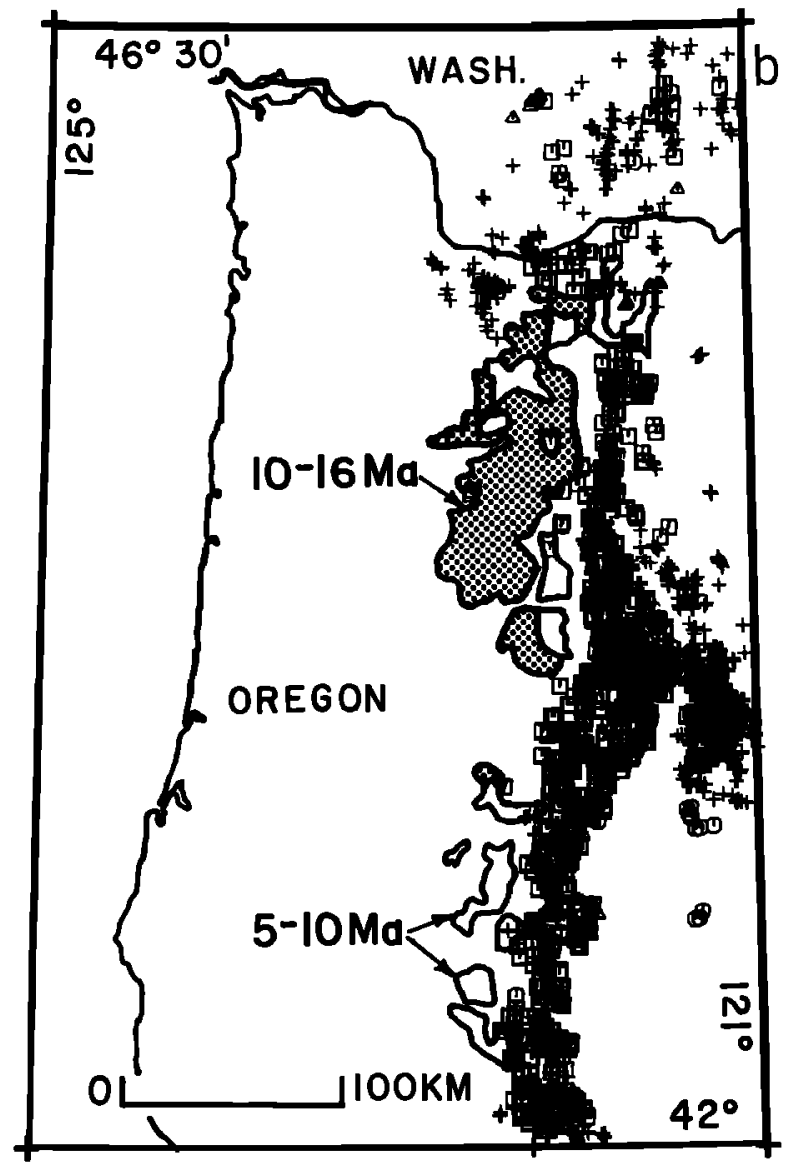

Fig. 2. (continued)

straight line [e.g., Stoiber and Carr, 1973; Carr et al., 1976; Hughes et al., 1980]. By using such a method, Stoiber and Carr [1973] divided historically active volcanoes of the Central American arc into seven linear segments and characterized boundaries between segments as areas of normal faulting, concentrated shallow seismicity, basaltic cinder cones, and catastrophic large eruptions. The boundaries between segments were modeled as tear faults that break the subducting Cocos plate into separate blocks of differing strikes and dips; these lower plate variations were assumed to give rise to the observed volcanic segmentation.

In the Nazca subduction zone beneath South America the areal occurrence of volcanism has been related to the distribution of seismicity. Areas of moderate crustal seismicity and limited Cenozoic volcanism overlie shallow dipping portions of the Nazca plate, whereas areas having few crustal earthquakes and extensive Cenozoic volcanism overlie more steeply dipping sections of the Nazca plate [Barazangi and Isacks, 1979; Jordan et al., 1983]. In both the Nazca and Cocos subduction zones the occurrence of Wadati-Benioff zone earthquakes along most of the strike of the subduction zone allows the relation between surface volcanism and the configuration of the subducting plate to be established.

Both segmentation models (alignment of stratovolcanoes and the areal distribution of seismicity and volcanism) have been applied to the Cascade Range. Hughes et al. [1980] applied the alignment model to the Cascades and divided the arc into six linear segments, ranging from 110 to $240 \mathrm{~km}$ in length: Mount Garibaldi-Glacier Peak, Glacier Peak-Mount St. Helens, Mount Adams-Three Sisters, Three Sisters-Crater
Lake, Crater Lake-Mount Shasta, and Mount Shasta-Lassen Peak. Hughes et al. [1980] postulated that irregularities and changes in strike of the base of the continental slope indicate segmentation of the convergent margin; however, they cited no independent topographic, structural, or seismic evidence for this segmentation. Hughes et al. [1980] noted that these inferred margin segments, if extrapolated northeastward in the direction of convergence of the Juan de Fuca and North American plates, correlate with boundaries between volcanic segments. Our segments do not coincide with those of Hughes et al. [1980] because we use the distribution and composition of 2821 vents formed during the past $5 \mathrm{~m}$.y. rather than offsets in the alignment of about 20 recently active volcanic centers. Also, we consider vent distributions within segments, in addition to the locations of boundaries between segments.

Weaver and Michaelson [1985] used the earthquake distribution and the areal extent of late Cenozoic volcanism to divide the northern Cascade Range into three segments: Mount Baker to Mount Rainier, Mount Rainier to Mount Hood, and Mount Hood south. The two northern segments are similar to segments one and two in our model, but the segment boundaries are shown by Weaver and Michaelson [1985] as lines parallel to the plate convergence direction $\left(\mathrm{N} 50^{\circ} \mathrm{E}\right)$. We do not specify any orientation of segment boundaries on Figure 6 because we cannot independently confirm them to be linear physical features in the continental crust or subducting slab.

\section{Regional Tectonic Considerations}

\section{Structural Elements of the Juan de Fuca Plate}

At present, the Juan de Fuca plate system consists of small remnants of the Farallon plate, which was subducting beneath most of the west coast of North America until about $30 \mathrm{Ma}$, when the San Andreas transform fault system began to form and grow in length north and south [Atwater, 1970]. The Juan de Fuca plate is bounded by two smaller subplates, the Explorer on the north and the Gorda on the south (Figure 6). The plate system has a history of complex motion in the late Cenozoic. Since $7 \mathrm{Ma}$, the oblique convergence of the Juan de Fuca plate (relative to the North American plate) has decreased from $6-7 \mathrm{~cm} / \mathrm{yr}$ to the present comparatively slow rate of 3-4 cm/yr [Riddihough, 1977, 1984]. The Explorer plate separated from the Juan de Fuca plate along the Nootka fault about $4 \mathrm{Ma}$ [Hyndman et al., 1979], a process associated with the westward shift of the Garibaldi volcanic belt in southern British Columbia, relative to the older Pemberton belt [Bevier et al., 1979]. The Explorer plate apparently is no longer subducting beneath North America and instead could be pivoting about a pole of motion different from the rest of the plate system [Riddihough, 1984]. The Gorda and Juan de Fuca ridges separated by rift propagation between 18 and $5 \mathrm{Ma}$ [Wilson et al., 1984]. The Gorda plate appears to have deformed in a largely nonrigid manner, and its motion has been modeled assuming both convergence with the Mendocino transform [Stoddard, 1987] and no convergence [Wilson, 1986]. In Figure 6, we illustrate plate geometry for the past 1 m.y. [from Riddihough, 1984], which is the configuration associated with the majority of vents formed since $5 \mathrm{Ma}$.

In most subduction zones the occurrence of earthquakes along the Wadati-Benioff zone indicates that the subducting plate is about $100-150 \mathrm{~km}$ below the volcanic arc [e.g., Gill, 1981; Isacks and Barazangi, 1977], and the geometry of the 


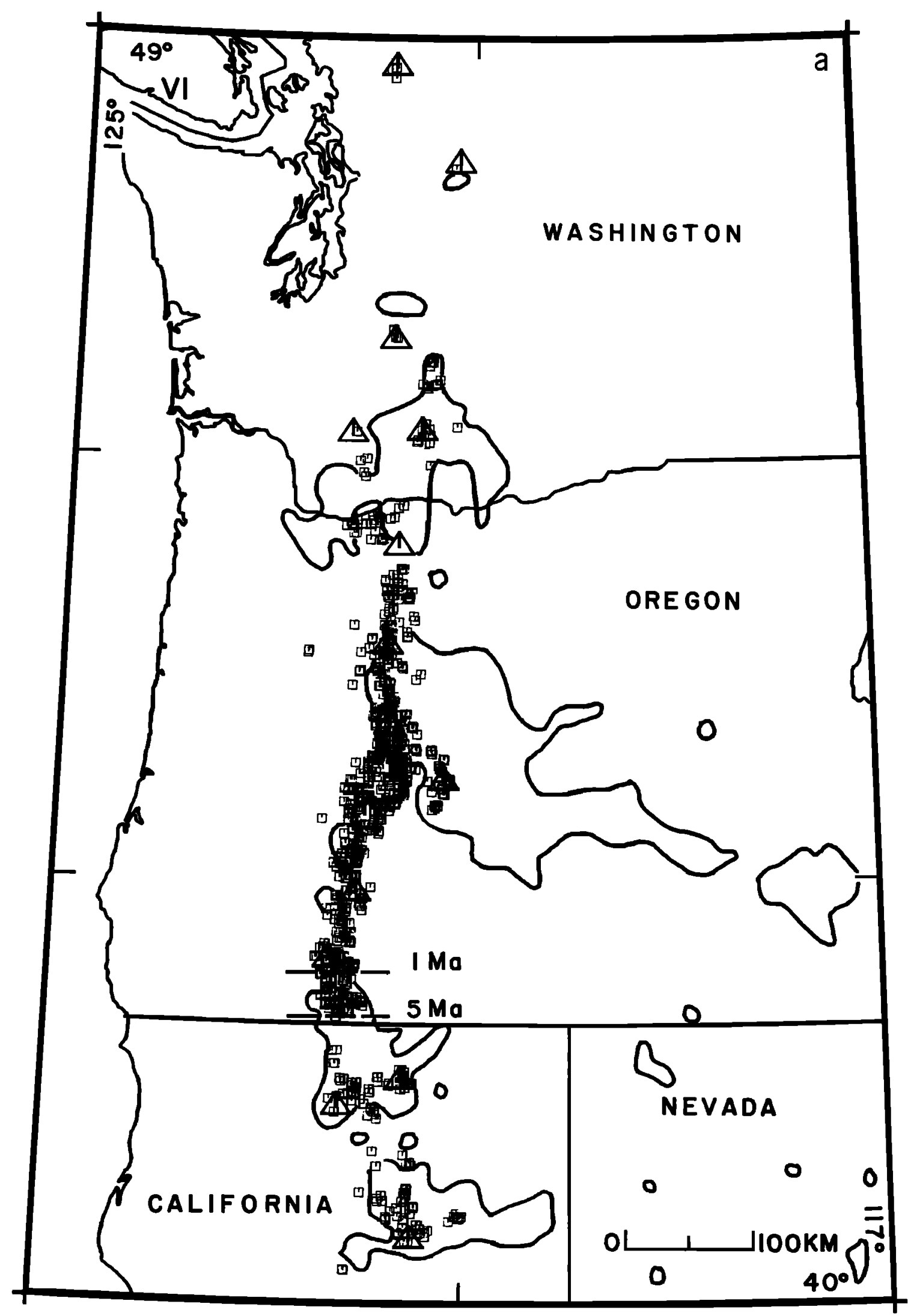

Fig. 3. Map of volcanic vents younger than $5 \mathrm{Ma}$ in the Cascade Range and adjacent areas, showing andesitic and basaltic vents separately: (a) 814 andesitic vents (squares), with outline of area of basaltic vents taken from Figure $3 b$; Horizontal dashed lines show southern extent of andesitic arc in Oregon at 1 and $5 \mathrm{Ma} ;(b) 1780$ basaltic vents (pluses), with outline of area of andesitic vents taken from Figure $3 a$. 


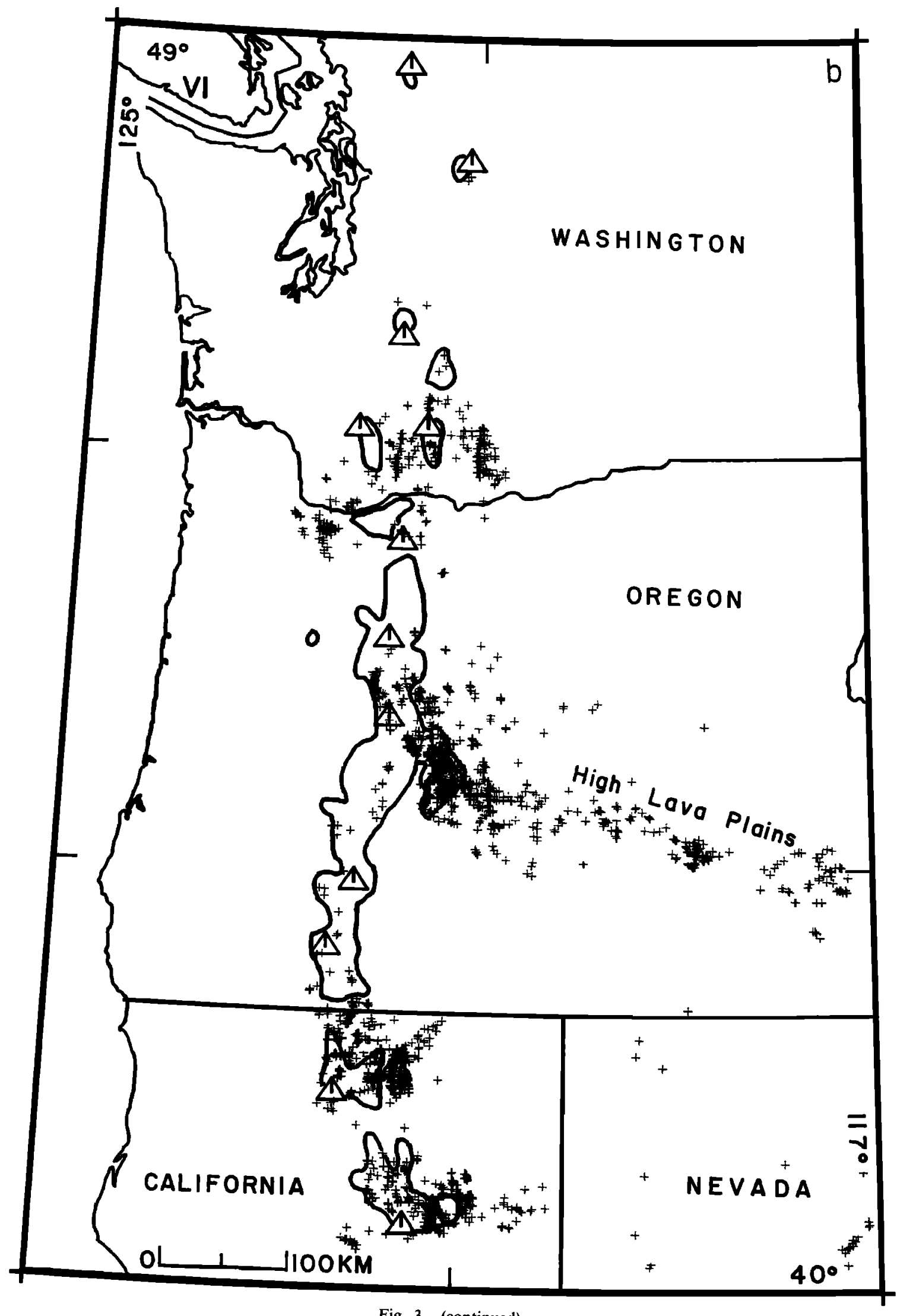

Fig. 3. (continued)

subducting plate from the trench to the volcanic arc can be inferred from Wadati-Benioff zone earthquakes. In the Pacific Northwest, however, Wadati-Benioff zone earthquakes have been located only beneath western Washington, northern
Oregon, and northern California, west of the Cascade arc generally at depths less than $80 \mathrm{~km}$ [Weaver and Baker, 1988; Walter, 1986; Cockerham, 1984]. Although the position of the plate directly beneath the Cascade arc is conjectural, it is rea- 


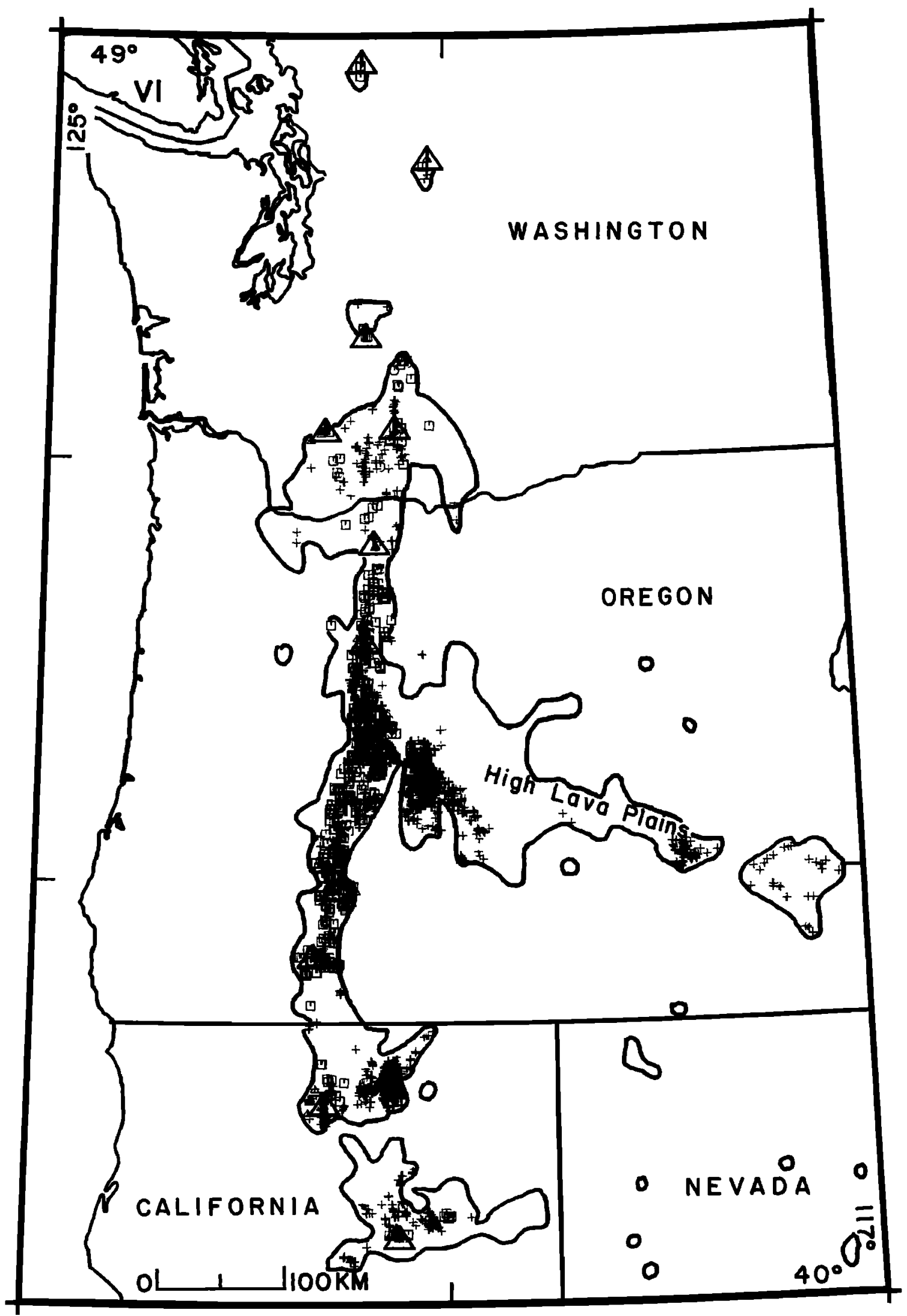

Fig. 4. Map of 1711 volcanic vents younger than $1 \mathrm{Ma}$ in the Cascade Range and adjacent areas, with outline of area of vents formed from 1 to $5 \mathrm{Ma}$ taken from Figure 2. Pluses, basalt; squares, andesite; triangles, dacite; circles, rhyolite.

sonable to assume that the arc volcanism of the past 5 m.y. is the result of magma genesis associated with location of the Juan de Fuca plate at a depth of about $100 \mathrm{~km}$ beneath the Cascade arc. Walter [1986], for example, notes that near
Lassen Peak the continued projection of the Gorda plate at $25^{\circ}$ dip (determined from seismicity at depths of $50-80 \mathrm{~km}$ ) would place the plate at a depth of approximately $100 \mathrm{~km}$ beneath the volcanic arc. 
In Figure 6 we show the location of $40-$ and $60-\mathrm{km}$ contours of depth to the subducting plate, which have been inferred from the known distribution of earthquake hypocenters in the upper part of the Juan de Fuca and Gorda plates [from Weaver and Baker, 1988; Walter, 1986; Cockerham, 1984]. There is no seismicity to constrain the position of the plate beneath most of Oregon. Weaver and Baker [1988] noted that beneath the Puget Sound basin, the Juan de Fuca plate has an upward undulation or arch between a depth of 40 and $60 \mathrm{~km}$; north of the arch the Juan de Fuca plate dips to the NE, and south of it the plate dips to the ESE (dip is approximately perpendicular to plate depth contours in Figure 6). As a result, the horizontal distance from the convergent margin to the $60-\mathrm{km}$ contour is greatest $(300 \mathrm{~km})$ where the plate arches upward and decreases to about $200 \mathrm{~km}$ elsewhere beneath southwestern Washington, Vancouver Island, and northern California.

Within this context, we are able to relate our segmentation of the Cascade Range to gross structural elements of the Juan de Fuca plate. We cannot unambiguously determine the position of the subducting plate solely from the distribution of volcanism. However, from the spatial relation between the vent distributions and subcrustal seismicity, we conclude that the volcanic segments reflect the subducting-plate geometry, which varies along the length of the subduction system.

North of the plate arch, the stratovolcanoes in British Columbia and northern Washington represent a NW trending volcanic front (defined here as the most trenchward extent of volcanism formed since $5 \mathrm{Ma}$ ), which is approximately parallel to the $60-\mathrm{km}$-depth contour of the plate and perpendicular to the direction of relative convergence $\left(\mathrm{N} 50^{\circ} \mathrm{E}\right)$ between the Juan de Fuca and North American plates. The volcanic gap between segments one and two is landward of the plate arch, that portion of the subducting plate having the least average dip (approximately $11^{\circ}$ ) between the margin and a depth of 60 $\mathrm{km}$. In segment two the NE trending volcanic front from Mount Rainier to the basaltic vents near Portland, Oregon, also is approximately parallel to the $60-\mathrm{km}$ plate depth contour to the west, but the volcanic front (and plate depth contour) is approximately perpendicular to the spreading direction of the Juan de Fuca ridge. The volcanic front of segment one is farther east of the $60-\mathrm{km}$ contour than the volcanic front of segment two, perhaps reflecting a steeper dip of the subducting plate beneath segment two at depths greater than $60 \mathrm{~km}$. Segments three and four are landward of the seismically quiet portion of the subduction system where no plate contours can be delineated. The volcanic front of segment five also is roughly parallel to the $60-\mathrm{km}$ plate contour and perpendicular to the ridge-spreading direction, as is segment two.

Figure 6 illustrates that terminations of the $60-\mathrm{km}$ plate contours in northern Oregon and northern California coincide with boundaries between our independently defined volcanic segments. It is evident from the offset of the discontinuous contours that additional variation in the geometry of the Juan de Fuca plate is expected in the seismically quiet portion of the plate. We infer from the parallel relation of the subducting-plate contours and the volcanic front observed in segments one, two, and five that the Juan de Fuca plate should have a nearly uniform geometry everywhere beneath segment three and four. Consequently, the expected additional variations in subducting-plate geometry likely occur near the boundaries between volcanic segments two and three and between segments four and five. The volcanic front of segment three is farther east than the volcanic front of segment two, and the $60-\mathrm{km}$ plate depth contour likewise may be offset to the east beneath northern Oregon. The narrowness of the vent distribution in segment three implies that the zone of magma generation is confined to a small volume of the upper mantle, perhaps because the Juan de Fuca plate dips steeply through the magma genesis zone. This inference is in agreement with the interpretation of Michaelson and Weaver [1986] that teleseismic $P$ wave delays observed beneath the northern end of segment three indicate a steep dip (approximately $70^{\circ}$ ) of the Juan de Fuca plate beneath the Cascade Range in northern Oregon.

In the case of segments four and five the volcanic front near Lassen volcanic center, which overlies the Gorda North plate, is positioned about $50 \mathrm{~km}$ farther east of the convergent margin than the volcanic front near Mount Shasta. Consequently, northward linear extrapolation of the $60-\mathrm{km}$ contour west of Lassen Peak yields an improbably shallow depth of approximately $60 \mathrm{~km}$ to the subducting slab beneath Mount Shasta. If the volcanic front of segment four occurs approximately $50 \mathrm{~km}$ east of the $60-\mathrm{km}$ contour, as it does in segment five, then the $60-\mathrm{km}$ contour of segment four probably is offset to the west between the Shasta and Lassen volcanic centers. If the volcanic front of segment four is closer than $50 \mathrm{~km}$ to the 60-km contour, then the Juan de Fuca plate is dipping more steeply than the Gorda North plate at depths greater than 60 $\mathrm{km}$. In either instance, a change in the configuration of the subducting slab is implied between the Shasta and Lassen centers. Since approximately $4 \mathrm{Ma}$, the Gorda North plate has been the youngest oceanic crust to subduct, and the presumably hotter and more buoyant crust may have greater resistance to subduction [Riddihough, 1984]. Between segments four and five, the inferred change in geometry of the Juan de Fuca and Gorda North plates may be related to this difference in subduction. Upper crustal $(<20 \mathrm{~km})$ composition also changes from granitic Sierra Nevadan basement beneath the Lassen center [Berge and Stauber, 1987] to metamorphic and ultramafic basement of the Klamath Mountains Province beneath Mount Shasta [Fuis et al., 1987], but is is unclear how this variation translates into differences in position of the two volcanic centers.

Spatial congruence between segmentation of a volcanic arc and geometry of a subducting plate is not always observed where the two features are determined independently. Burbach and Frohlich [1986] used hypocenter data to examine systematically the changes in subduction zone geometry around the Pacific. They noted that $68 \%$ of the probable segment boundaries, defined using earthquake hypocenters as areas where the subduction geometry changed, were associated with noticeable changes in arc volcanism but that these changes seldom coincided exactly and were often separated by as much as $100 \mathrm{~km}$. Our ability to match more closely the inferred changes in plate geometry and volcanic arc segmentation in the Pacific Northwest is likely the result of our considering longer time intervals and using all of the volcanic vents.

In addition to the influence of plate geometry, we also recognize the effect of crustal structures and processes on localization of volcanism. The sites of major Cascade stratovolcanoes and composite centers likely involve crustal focusing of mantle-derived basalt, along the lines described by Hildreth [1981]. In Oregon and northern California, major centers commonly are associated with grabens and normal faulting. Mount Jefferson and Three Sisters are located within the central Oregon High Cascades graben [Smith and Taylor, 1983]. Mount Hood lies west of the Hood River normal fault and 


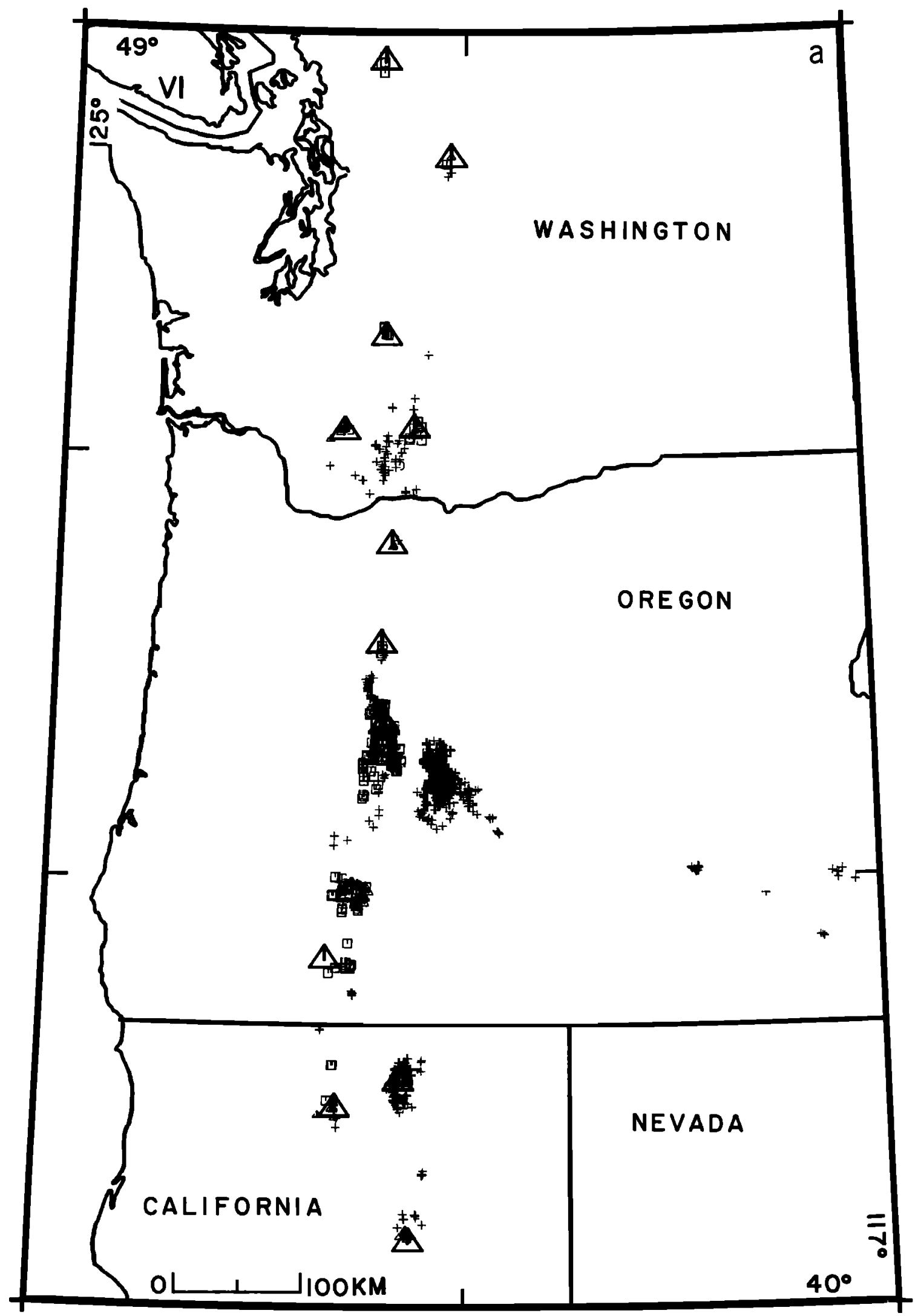

Fig. 5. Map of volcanic vents younger than $0.1 \mathrm{Ma}$ in the Cascade Range and adjacent areas: (a) 837 vents of all compositions (pluses, basalt; squares, andesite; triangles, dacite; circles, rhyolite); (b) 103 dacitic (triangles) and rhyolitic (circles) vents. Large triangles in Figure $5 b$ are major Quaternary volcanoes lacking rhyolitic or dacitic vents younger than $0.1 \mathrm{Ma}$. 


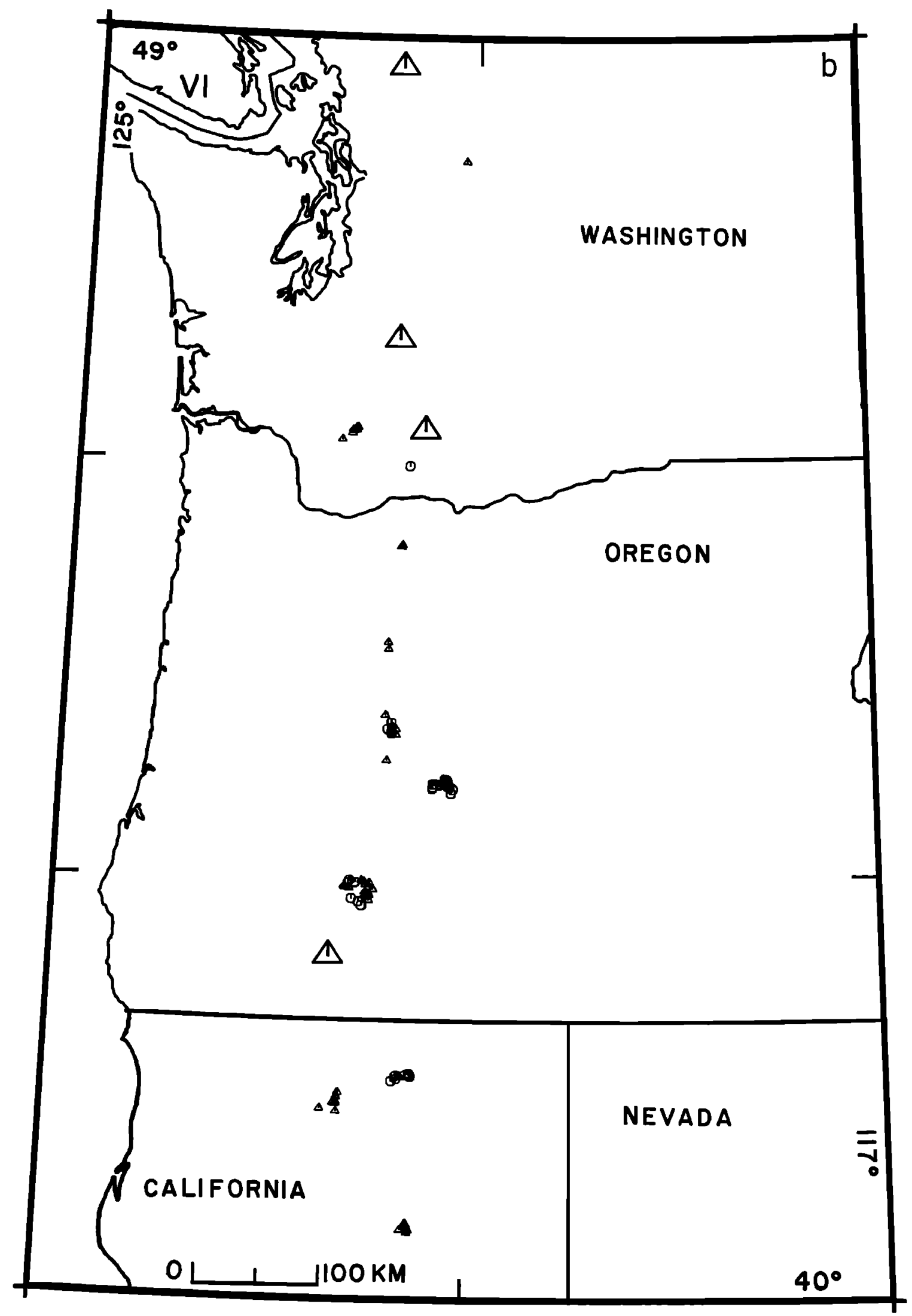

Fig. 5. (continued)

possibly within the northward extension of the central Oregon graben [Williams et al., 1982]. Crater Lake and Medicine Lake volcanic centers lie at the NW and SE ends, respectively, of the Klamath graben which abuts the Cascade arc on the east [Lawrence, 1976; Donnelly-Nolan, 1983]. Lassen volcanic center lies between the Lake Almanor and Hat Creek grabens (L. J. P. Muffler, oral communication, 1987). In southern Washington, Mount St. Helens is located where dextral offset 


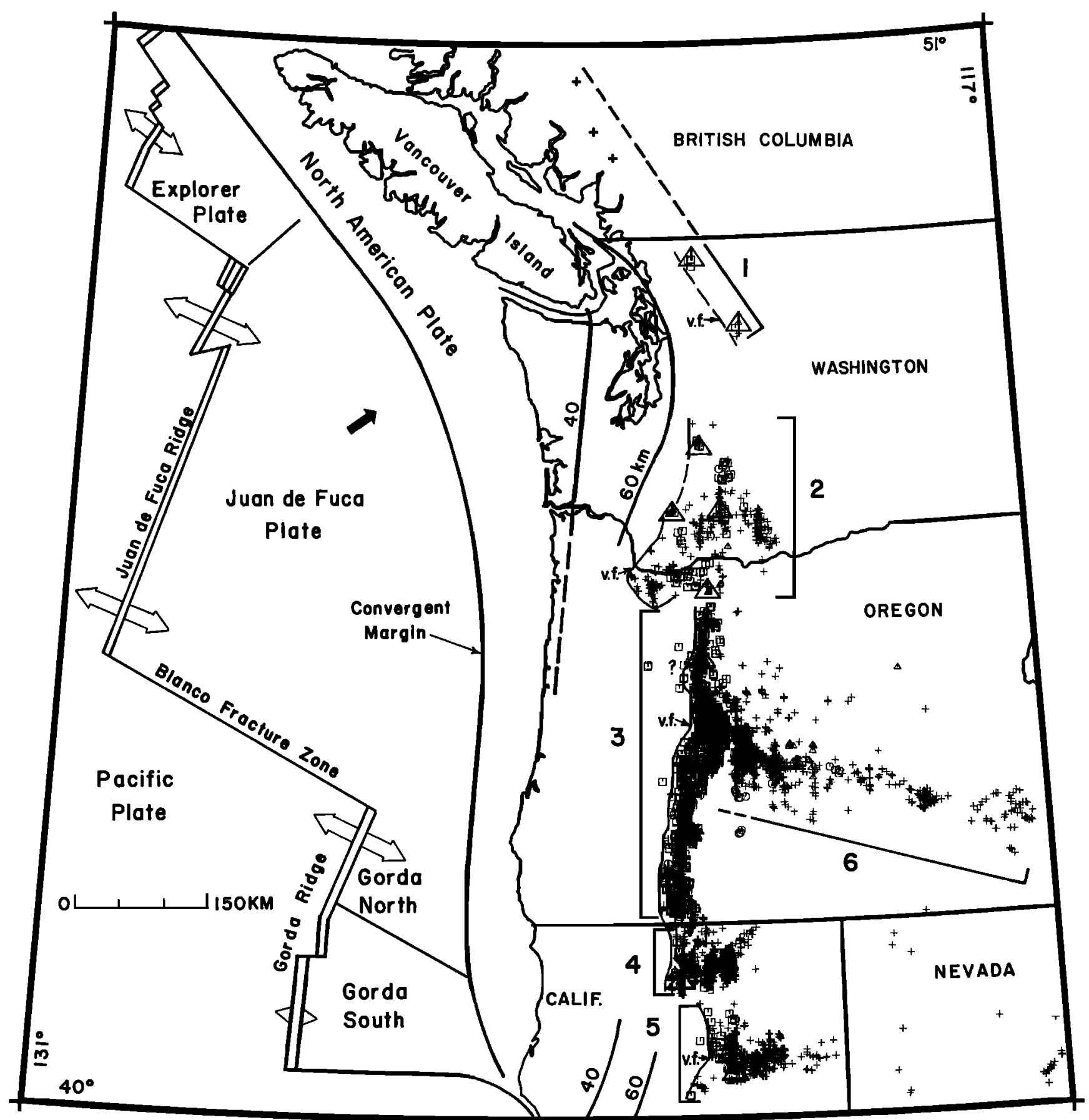

Fig. 6. Map showing plate tectonic features of the Juan de Fuca-North American subduction system [from Riddihough, 1984] in relation to volcanic segmentation of the Cascade arc based on distribution of vents less than 5 m.y. old. Open arrows show ridge-spreading directions; solid arrow shows direction of convergence between the Juan de Fuca and North American plates. Numbers refer to volcanic arc segments discussed in text. Bold brackets delineate the segments and are dashed at ends where there is uncertainty as to the boundary (see text). The 40- and 60-km contours (dashed where uncertain) show depth of selsmicity in the upper part of the Juan de Fuca and Gorda plates [from Weaver and Baker, 1988]. Volcanic front (v.f.) is indicated by light line along westernmost edge of the volcanic vents (dashed where few vents, queried where uncertain). Pluses, basalt; squares, andesite; triangles, dacite; circles; rhyolite. Bold crosses show generalized Quaternary volcanic centers in British Columbia: (from north to south) Meager Mountain, Mount Cayley, Mount Garibaldi.

of the right-lateral strike-slip St. Helens seismic zone creates local crustal extension and intersects preexisting NE trending structures [Weaver et al., 1987]. In the northern Washington Cascades the crustal regime apparently is more strongly compressional [Rogers, 1985; Weaver and Michaelson, 1985], and volcanism is confined to large, widely spaced stratovolcanoes
(Mount Baker and Glacier Peak). However, even allowing for controls by the crustal stress field as exemplified above, the congruence of the volcanic segments and subducting-plate geometry remains discernible. This congruence implies that the extent of subduction-related magma generation in the mantle is sufficiently well represented by surface volcanism. 


\section{Basin and Range Impingement}

An interesting aspect of the regional tectonic framework in which subduction takes place is the presence of the extensional Basin and Range province in the North American plate adjacent to the volcanic arc. The westward migration of Basin-and-Range volcanism toward the Cascade arc is well depicted in Figures 1 and $2 a$. We use the term "impingement" for the occurrence of Basin-and-Range volcanism adjacent to the Cascade arc. Impingement of the NW trending belt of Basin-and-Range vents took place during the interval 5-10 Ma (Figure 1 b), apparently first in the vicinity of the most northwestern group of andesitic and basaltic vents between present-day Crater Lake and Newberry volcanoes. Comparison of Figure $1 b$ with Figure $2 a$ shows that since $5 \mathrm{Ma}$, volcanic activity ceased in the area of vents active from 5 to 10 $\mathrm{Ma}$ in south central Oregon and northeastern California; vents formed since $5 \mathrm{Ma}$ in southern Oregon occur exclusively in the narrow Cascade arc. After this cessation of Basin-andRange volcanism, subduction zone geometry defines the overall volcanic pattern in southern Oregon.

Since $5 \mathrm{Ma}$, basaltic volcanism has continued east of Medicine Lake and Lassen Peak (Figure $2 a$ ), perhaps because the leading edge of the NNW trending belt of Basin-and-Range volcanism impinges successively southward against the Cascade arc. If so, basaltic volcanism on the eastern flanks of the Cascade Range in northern California may identify where impingement is not complete in this time period. Since $5 \mathrm{Ma}$, volcanism has been more localized around Mount Shasta, Medicine Lake, and Lassen Peak (compare Figures $3 b$ and 4).

The impingement process may result in reorientation of crustal stress. For example, in the Lassen region westward volcanic contraction [Grose and McKee, 1982] has been accompanied by a $90^{\circ}$ change in direction of least principal stress as evidenced by fault trends and volcanic alignments [Grose, 1985]. Over a distance of about $50 \mathrm{~km}$, the direction of least principal stress changed from NW-SE during the period from 10 to $12 \mathrm{Ma}$ in the Walker Lane of the Basin and Range province to SW-NE during the interval from 0 to $2 \mathrm{Ma}$ directly adjacent to Lassen Peak [Grose, 1985; Grose and McKee, 1986]. The coeval volcanic progression and stress changes in the Lassen vicinity appear to document the migration of Basin-and-Range volcanism into the Cascade region.

Juxtaposition of Basin-and-Range volcanism and tectonism with the Cascade arc also occurs where faulting and volcanism along the High Lava Plains intersect the arc in the vicinity of Three Sisters and Newberry volcanoes. The Brothers fault zone, the structural component of the High Lava Plains, comprises closely spaced, en echelon normal faults that have localized basaltic and rhyolitic vents since the late Miocene [Walker, 1969, 1977]. This surface zone of normal faulting is inferred to overlie a deeper, right-lateral strike-slip fault zone [Lawrence, 1976]. The west end of the Brothers fault zone merges northward into the Green Ridge vnormal fault that strikes N-S on the east side of the Cascade $\backslash$ Range between Three Sisters and Mount Jefferson. In this region, discontinuous normal fault occur on both sides of the Quaternary arc and structurally define the central Oregon High Cascades graben of Smith and Taylor [1983], who proposed that the graben was formed by regional extension associated with late Miocene mafic volcanism in central Oregon. Smith et al. [1987] concluded that extension-related Cascade volcanism began there about $7 \mathrm{Ma}$, followed by development of the intra-arc graben about $5.3 \mathrm{~m}$.y. ago as represented by the
Green Ridge fault. Sherrod [1986] concluded that there is no structural or stratigraphic evidence for a continuous High Cascades graben elsewhere throughout Oregon, although smaller localized grabens do occur along the boundary between the Quaternary Cascades and the Basin and Range province. Thus major graben structure in the Cascades is most clearly evident in the vicinity of the intersection of the High Lava Plains, and the extensional volcanism that led to the development of the central Oregon graben is approximately coincident in time with impingement of Basin-and-Range volcanism within the period from 5 to $10 \mathrm{Ma}$.

\section{Discussion}

The fundamental cause of the volcanic migration in the Pacific Northwest is speculative. Christiansen and McKee [1978] postulated that volcanic migration in the northern Basin and Range province is caused by progressive concentration of extension and volcanism in a zone of brittle deformation; this brittle zone has expanded outward along the western and eastern margins of the Basin and Range province because of decreased rigidity of the initial rift zone in central Nevada. Thus volcanism may reflect propagating stress relief.

Extension-related volcanism in the Cascades has been linked to a variety of factors including subduction oblique to the convergent margin [Rogers, 1985; Bacon, 1982], increase in the spreading rate of the Basin and Range province [Priest et al., 1983], and decrease in convergence rate between the Juan de Fuca and North American plates [Walker and Naslund, 1986; Hughes and Taylor, 1986]. While we cannot rule out the effect of some combination of these factors, we emphasize that regional tectonic models also should account for the observed migration of extensional Basin-and-Range volcanism adjacent to (and possibly into?) the Cascade Range.

In a plate tectonic framework the issue arises as to whether the Basin and Range province effectively acts as a back arc basin to the Cascade Range. Certainly, the major episode of subduction largely had ceased along the coast of California when extension began in Nevada $17 \mathrm{~m} . \mathrm{y}$. ago, and thus the entire Basin and Range province is not a back arc basin in a strict sense [Christiansen and McKee, 1978]. Nevertheless, Basin-and-Range extension is, at the least, spatially associated closely with the Cascade Range within the past 10 m.y. Furthermore, petrological investigations indicate that Basin-andRange lavas have geochemical affinities with back arc basin basalts; in northern California and southeastern Oregon east of the Cascades, low-potassium, low-titanium, high-alumina olivine tholeiites, chemically similar to circum-Pacific back arc basin basalts, were widespread in the late Miocene to Quaternary [McKee et al., 1983; Hart et al., 1984; Carlson and Hart, 1987]. However, the stratigraphic relations of this magma type to others within the Cascade arc is not yet clear.

The vent data do not allow us to deal explicitly with processes of magma generation. However, we wonder if Basinand-Range volcanism and Cascade volcanism may involve contrasting mantle magmatic regimes. That is, Basin-andRange impingement against the Cascade arc may juxtapose different regions of primary magma generation, one predominantly controlled by extensional tectonism and another deeper zone dominated by subduction-related melting. This question is best analyzed by geochemical arguments; however, the vent data presented here provide a regional context for addressing the issue.

More analysis of volumetric rates of volcanic production 
also is needed to understand processes of magma generation and crustal transport throughout the Cascade Range. Smith [1987] has estimated the volcanic production rate from north of Mount Rainier to the Columbia River (our segment two) to be $6.5 \mathrm{~km}^{3}$ per kilometer of arc length over for the past $1 \mathrm{~m} . \mathrm{y}$. Sherrod [1986] calculated a roughly equivalent extrusion rate, 3-6 $\mathrm{km}^{3}$ per kilometer of arc length per million years, for central Oregon between $43^{\circ}$ and $44^{\circ} \mathrm{N}$ (part of our segment three). Interestingly, this similarity of rates occurs in areas with different volcanic expression: southern Washington, dominated by large stratovolcanoes, and part of Oregon, located between major volcanic centers.

Further refinements of the temporal and compositional trends presented here will require an improved vent data set. A new geologic map compilation of the Cascade Range in Washington, Oregon, and California is underway [Smith, 1987; Sherrod, 1987] and will provide an updated vent data set based on additional geochronological and geochemical analyses. Geologic mapping of volcanic centers in the Canadian Cascade Range also is being compiled (C. Hickson, oral communication, 1987).

As a final note, we point out that our assumption linking the presence of an andesitic volcanic arc with the presence of a subducting plate at a depth sufficient for melting processes to be sustained is a major departure from the interpretation of the Cascade Range of McBirney [1978] and McBirney and White [1982]. These authors have suggested that there is little direct evidence to link volcanism in the Pacific Northwest with subduction; in their view, even the spatial relation of the volcanic arc to a subducting plate is ambiguous because the linear belt of andesitic volcanism observed today has not been a persistent feature of the Cascade Range. In our view, the apparent lack of a persistent volcanic arc throughout the long history of convergence in the Pacific Northwest does not invalidate the commonly acknowledged relation between andesitic volcanism and plate subduction. We are particularly impressed with correlation of volcanic segments with inferred subducting-plate geometry. Furthermore, we suggest that the length of the Cascade arc alone is difficult to explain without invoking causal, plate-scale interactions.

\section{Conclusions}

Pronounced spatial, temporal, and compositional variations in volcanism in the Cascade Range are exhibited by distributions of volcanic vents formed since $16 \mathrm{Ma}$, and therefore no single section across the range is representative of volcanism for the entire range. On the basis of the spatial distribution of nearly 3000 vents formed since $5 \mathrm{Ma}$, the Cascade Range can be divided into five segments, with the High Lava Plains constituting a sixth. Some aspects of the segmentation model can be related to inferred structural elements of the Juan de Fuca and Gorda plates. The relation of plate depth contours to the volcanic front indicates that the volcanic segments reflect the variable geometry of the subducting slab. The volcanic front is parallel to the strike of the Juan de Fuca plate, being perpendicular to convergence direction in northern Washington but approximately perpendicular to the ridgespreading direction in southern Washington, northern Oregon, and northern California. A volcanic gap between Mount Rainier and Glacier Peak is east of the portion of the subducting plate having the least average dip to a depth of 60 $\mathrm{km}$. A narrow, $\mathrm{N}$-S trending andesite-rich belt in Oregon is landward of the seismically quiet portion of the subduction zone; the eruption of andesite in a narrow zone suggests that the Juan de Fuca plate dips steeply beneath the Cascade arc throughout Oregon. The paucity of vents between the Mount Shasta and Lassen centers occurs between the Juan de Fuca and Gorda North plates, which have differing age, amounts of subcrustal seismicity, and probably geometry. Breaks in offset contours of plate depth coincide with independently defined boundaries between volcanic segments in northern Oregon and northern California.

Vent patterns developed since 16 Ma depict the migration of Basin-and-Range volcanism toward the Cascade arc. In Oregon, Basin-and-Range volcanism migrated west to the Cascade arc (defined here as "impingement") from 5 to $10 \mathrm{Ma}$, and Basin-and-Range volcanism in southern Oregon ceased since $5 \mathrm{Ma}$. In contrast, basaltic volcanism east of the Cascade Range continued in the past $5 \mathrm{~m}$.y. in northeastern California where the impingement process apparently is not yet complete. Contraction of the area of basaltic volcanism during the past 5 m.y. around Mount Shasta, Medicine Lake, and Lassen Peak occurred as Basin-and-Range volcanism migrated toward the subduction-related volcanic system in northern California. In central Oregon, where the High Lava Plains intersect the Cascade arc, impingement approximately coincides in time with commencement of extension-related volcanism and development of the High Cascade graben between Three Sisters and Mount Jefferson.

Acknowledgments. We thank James Allan, Wes Hildreth, Clifford Hopson, and Wendell Duffield for helpful reviews. We also benefited from comments from Charles Bacon, Thomas Bullen, Geofirey Clayton, Michael Clynne, Robert Luedke, Patrick Muffler, David Sherrod, James Smith, and Robert Smith. We are very grateful to Toni Medlin for use of her digitizing system and to the Reston Seismic Group for computer support and consultation. This research was supported by the U.S. Geological Survey Geothermal Research Program and Earthquake Hazards Reduction Program.

\section{REFERENCES}

Atwater, T., Implications of plate tectonics for the Cenozoic tectonic evolution of western North America, Geol. Soc. Am. Bull., 81, 3513$3536,1970$.

Bacon, C. R., Geology and geophysics of the Cascade Range, Geophysics, 47, 423-424, 1982.

Bacon, C. R., Implications of silicic vent patterns for the presence of large crustal magma chambers, J. Geophys. Res., 90, 11,243-11,252, 1985.

Barazangi, M., and B. L. Isacks, Subduction of the Nazca plate beneath Peru: Evidence from spatial distribution of earthquakes, Geophys. J. R. Astron. Soc., 57, 537-555, 1979.

Beck, M. E., Jr., R. F. Burmester, D. E. Craig, C. S. Gromme, and R. E. Wells, Paleomagnetism of middle Tertiary volcanic rocks from the Western Cascade series, northern California, J. Geophys. Res., 9I, 8219-8230, 1986.

Beeson, M. H., R. Perttu, and J. Perttu, The origin of the Miocene basalts of coastal Oregon and Washington: An alternative hypothesis, Oreg. Geol., 41, 159-166, 1979.

Berge, P. A., and D. A. Stauber, Seismic refraction study of uppercrustal structure in the Lassen Peak area, northern California (abstract), Eos Trans. AGU, 68, 591, 1987.

Bevier, M. L., R. L. Armstrong, and J. G. Souther, Miocene peralkaline volcanism in west-central British Columbia-Its temporal and plate-tectonics setting, Geology, 7, 389-392, 1979.

Burbach, G. V., and C. Frolich, Intermediate and deep seismicity and lateral structure of subducted lithosphere in the circum-Pacific region, Rev. Geophys., 24, 833-874, 1986.

Carlson, R. W., and W. K. Hart, Crustal genesis on the Oregon Plateau, J. Geophys. Res., 92, 6191-6206, 1987.

Carr, M. J., R. E. Stoiber, and C. L. Drake, The segmented nature of some continental margins, in The Geology of Continental Margins, edited by C. A. Burk and C. L. Drake, pp. 105-114, SpringerVerlag, New York, 1976.

Christiansen, R. L., and P. W. Lipman, Cenozoic volcanism and plate 
tectonic evolution of the western United States, part II, Late Cenozoic, Philos. Trans. R. Soc. London, Ser. A, 271, 249-284, 1972.

Christiansen, R. L., and E. H. McKee, Late Cenozoic volcanic and tectonic evolution of the Great Basin and Columbia Intermontane regions, Mem. Geol. Soc. Am., 152, 283-311, 1978.

Cockerham, R. S, Evidence for a $180-\mathrm{km}$-long subducted slab beneath northern California, Bull. Seismol. Soc. Am., 74, 569-576, 1984.

Donnelly-Nolan, J., Structural trends and geothermal potential at Medicine Lake volcano, northeastern California (abstract), Eos Trans. $A G U, 64,898,1983$.

Fuis, G. S., J. J. Zucca, W. D. Mooney, and B. Milkereit, A geologic interpretation of seismic-refraction results in northeastern California, Geol. Soc. Am. Bull., 98, 53-65, 1987.

Gill, J. B., Orogenic Andesites and Plate Tectonics, 390 pp., SpringerVerlag, New York, 1981.

Grommé, C. S., M. E. Beck, Jr., R. E. Wells, and D. C. Engebretson, Paleomagnetism of the Tertiary Clarno Formation of central Oregon and its significance for the tectonic history of the Pacific Northwest, J. Geophys. Res., 9I, 14,089-14,103, 1986.

Grose, T. L. T., Volcanotectonic evidence for stress field changes since late Miocene in Basin and Range-Cascade boundary zone (Walker Lane) of northeastern California (abstract), Eos Trans. $A G U, 66$, $1091,1985$.

Grose, T. L. T., and E. H. McKee, Late Cenozoic westward volcanic progression east of Lassen Peak, northeastern California (abstract), Eos Trans. $A G U, 63,1149,1982$.

Grose, T. L. T., and E. H. McKee, Potassium-argon ages of late Miocene to late Quaternary volcanic rocks in the Susanville-Eagle Lake area, Lassen County, California, Isochron West, 45, 5-11, 1986.

Hart, W. K., J. L. Aronson, and S. A. Mertzman, Areal distribution and age of low-K, high-alumina olivine tholeiite magmatism in the northwestern Great Basın, Geol. Soc. Am. Bull., 95, 186-195, 1984.

Hildreth, W., Gradients in silicic magma chambers: Implications for lithospheric magmatism, J, Geophys. Res., 86, 10,153-10,192, 1981.

Hughes, J. M., R. E. Storber, and M. J. Carr, Segmentation of the Cascade volcanic chain, Geology, 8, 15-17, 1980.

Hughes, S. S., and E. M. Taylor, Geochemistry, petrogenesis, and tectonic implications of central High Cascade mafic platform lavas, Geol. Soc. Am. Bull., 97, 1024-1036, 1986.

Hyndman, R. D., R. P. Riddihough, and R. Herzer, The Nootka fault-A new plate boundary off western Canada, Geophys. J. R. Astron. Soc., 58, 667-683, 1979

Isacks, B. L., and M. Barazangi, Geometry of Benioff zones: Lateral segmentation and downwards bending of the subducted lithosphere, in Island Arcs, Deep Sea Trenches, and Back-Arc Basins, Maurice Ewing Ser., vol. 1, edited by M. Talwani and W. C. Pitman III, pp. 99-114, AGU, Washington, D. C., 1977.

Jordan, T. E., B. L. Isacks, R. W. Allmendinger, J. A. Brewer, V. A. Ramos, and C. J. Ando, Andean tectonics related to geometry of subducted Nazca plate, Geol. Soc. Am. Bull., 94, 341-361, 1983.

Lawrence, R. D., Strike-slip faulting terminates the Basin and Range province in Oregon, Geol. Soc. Am. Bull., 87, 846-850, 1976.

Luedke, R. G., and R. L. Smith, Map showing distribution, composition, and age of late Cenozoic volcanic centers in California and Nevada, scale $1: 1,000,000$, U.S. Geol. Surv. Misc. Invest. Ser., Map I-1091-C, 1981.

Luedke, R. G., and R. L. Smith, Map showing distribution, composition, and age of late Cenozoic volcanic centers in Oregon and Washington, scale $1: 1,000,000$, U.S. Geol. Surv. Misc. Invest. Ser., Map I-1091-D, 1982

MacLeod, N. S., G. W. Walker, and E. H. McKee, Geothermal significance of eastward increase in age of upper Cenozoic rhyolitic domes in southeastern Oregon, in Proceedings of the Second UN Symposium on the Development and Use of Geothermal Resources, vol. 1, pp. 465-474, U.S. Government Printing Office, Washington, D. C., 1976.

Magill, J., A. Cox, and R. Duncan, Tillamook volcanic series: Further evidence for tectonic rotation of the Oregon Coast Range, J. Geophys. Res., 86, 2953-2970, 1981.

McBirney, A. R., Volcanic evolution of the Cascade Range, Annu. Rev. Earth Planet. Sci., 6, 437-456, 1978.

McBirney, A. R., and C. M. White, The Cascade Province, in Andesites: Orogenic Andesites and Related Rocks, edited by R. S. Thorpe, pp. 115-135, John Wiley, New York, 1982.

McKee, E. H., W. A. Duffield, and R. J. Stern, Late Miocene and early Pliocene basaltic rocks and their implications for crustal structure, northeastern California and south-central Oregon, Geol. Soc. Am. Bull., 94, 292-304, 1983.

Michaelson, C. A., and C. S. Weaver, Upper mantle structure from teleseismic $\boldsymbol{P}$ wave arrivals in Washington and northern Oregon, $J$. Geophys. Res., 91, 2077-2094, 1986.

Priest, G. R., N. M. Woller, G. L. Black, and S. H. Evans, Overview of the geology of the central Oregon Cascade Range, Spec. Pap. Oreg. Dep. Geol. Miner. Ind., 15, 3-28, 1983.

Riddihough, R. P., A model for recent plate interactions off Canada's west coast, Can. J. Earth Sci., 14, 384-396, 1977.

Riddihough, R., Recent movements of the Juan de Fuca plate system, J. Geophys. Res., 89, 6980-6994, 1984.

Rogers, G. C., Variation in Cascade volcanism with margin orientation, Geology, 13, 495-498, 1985.

Sherrod, D. R., Geology, petrology, and volcanic history of a portion of the Cascade Range between latitudes $43-44^{\circ} \mathrm{N}$, central Oregon, USA, Ph.D. thesis, 320 pp., Univ. of Calif., Santa Barbara, 1986.

Sherrod, D. R., New compilation map of the Cascade Range in Oregon, Trans. Geotherm. Resour. Counc., 11, 305-307, 1987.

Smith, G. A., and E. M. Taylor, The central Oregon High Cascade graben: what? where? when?, Trans. Geotherm. Resour. Counc., 7, 275-279, 1983.

Smith, G. A., L. W. Snee, and E. M. Taylor, Stratigraphic, sedimentologic, and petrologic record of late Miocene subsidence of the central Oregon High Cascades, Geology, 15, 389-392, 1987.

Smith, J. G., New compilation geologic map of the Cascade Range in Washington, Trans. Geotherm. Resour. Counc., 11, 309-314, 1987.

Smith, R. L., and R. G. Luedke, Potentially active volcanic lineaments and loci in western conterminous United States, in Explosive Volcanism: Inception, Evolution, Hazards, pp. 47-66, National Academy Press, Washington, D. C., 1984.

Stoddard, P. R., A kinematic model for the evolution of the Gorda plate, J. Geophys. Res., 92, 11,524-11,532, 1987.

Stoiber, R. E., and M. J. Carr, Quaternary volcanic and tectonic segmentation of Central America, Bull. Volcanol., 37, 304-325, 1973.

Walker, G. W., Geology of the High Lava Plains province, Bull. Oreg. Dep. Geol. Miner. Ind., 64, 7-79, 1969.

Walker, G. W., Geologic map of Oregon east of the 121st meridian, scale 1:500,000, U.S. Geol. Surv Misc. Invest. Ser., Map I-902, 1977.

Walker, J. R., and H. R. Naslund, Tectonic significance of mildly alkaline Pliocene lavas in Klamath River Gorge, Cascade Range, Oregon, Geol. Soc. Am. Bull., 97, 206-212, 1986.

Walter, S. R., Intermediate-focus earthquakes associated with Gorda plate subduction in northern California, Bull. Seismol. Soc. Am., 76, 583-588, 1986

Weaver, C. S., and G. E. Baker, Geometry of the Juan de Fuca plate beneath Washington-Evidence from seismicity and the 1949 South Puget Sound earthquake, Bull. Seismol. Soc. Am., 78, 264 $275,1988$.

Weaver, C. S., and C. A. Michaelson, Seismicity and volcanism in the Pacific Northwest: Evidence for the segmentation of the Juan de Fuca plate, Geophys. Res. Lett., 12, 215-218, 1985.

Weaver, C. S., and S. W. Smith, Regional tectonic and earthquake hazard implications of a crustal fault zone in southwestern Washington, J. Geophys. Res., 88, 10,371-10,383, 1983.

Weaver, C. S., W. C. Grant, and J. E. Shemeta, Local crustal extension at Mount St. Helens, Washington, J. Geophys. Res., 92, 10,170-10,178, 1987 .

Williams, D. L., D. A. Hull, H. D. Ackermann, and M. H. Beeson, The Mount Hood region: Volcanic history, structure, and geothermal energy potential, J. Geophys. Res., 87, 2767-2781, 1982.

Wilson, D. S., A kinematic model for the Gorda deformation zone as a diffuse southern boundary of the Juan de Fuca plate, $J$. Geophys. Res., 9I, 10,259-10,269, 1986.

Wilson, D. S., R. N. Hey, and C. Nishimura, Propagation as a mechanism of reorientation of the Juan de Fuca ridge, J. Geophys. Res., $89,9215-9225,1984$

M. Guffanti, U.S. Geological Survey, 922 National Center, Reston, VA 22092 .

C. S. Weaver, Geophysical Program AK-50, University of Washington, Seattle, WA 98195.

(Received June 1, 1987; revised December 22, 1987; accepted January 26, 1988.) 